\title{
ASSESSING SAFETY LEVEL OF UTM CAMPUS BASED ON SAFE CITY CONCEPTS
}

\author{
S. Samsudin ${ }^{1}$, Z. Tarmidi ${ }^{1 *}$, NH. Adi Maimun ${ }^{2}$, NA. Mat Noor ${ }^{2}$, AN. Md Nasir ${ }^{3}$, A. Sidek ${ }^{4}$ \\ ${ }^{1}$ Geoinformation, Faculty of Built Environment and Survey, Universiti Teknologi Malaysia, 81310 UTM \\ Johor Bahru, Johor - shatirah@gmail.com, zakritarmidi@utm.my \\ ${ }^{2}$ Real Estate, Faculty of Built Environment and Survey, Universiti Teknologi Malaysia, 81310 UTM \\ Johor Bahru, Johor - nurulhana@utm.my, noorsidi@utm.my \\ ${ }^{3}$ Department of Technical and Engineering Education, School of Education, Faculty of Social Sciences and Humanities, Universiti \\ Teknologi Malaysia, 81310, Johor Bahru, Malaysia - ahmadnabil@utm.my \\ ${ }^{4}$ School of Chemical and Energy Engineering, Faculty of Engineering, Universiti Teknologi Malaysia, 81310, Johor Bahru, Malaysia \\ - akhmalsidek@utm.my
}

KEY WORDS: Safe City Concept, Safe City Spatial Indicators, Spatial Indicators, Campus Safety Level.

\begin{abstract}
:
Safety is an important aspect in today's living, in urban city, residential area, and also in campus area. Several initiatives were introduced to increase the safety level, and to prevent crime from happening in the campus area, known as Safe City Concept. These initiatives included the Safe City Index, Crime Prevention Through Environmental Design (CPTED), behavioural model, safe city urban area, safe city of smart city, and resident safety assessment. Some of this initiative focus on urban city area, or residential, besides only focus on crime prevention and not focus on the assessment of safety level for campus area. This study aims to assess the safety level for campus area, with case study of UTM Campus. To assess the safety level, a set 4 indicators, which is crime, environment, public health and emergency response, with 9 sub-indicators was identified in this study. These indicators and subindicators used to determine the safety level of campus area based on the Safe City Concept. The analysis used is spatial analysis on the indicator, and using weighted criteria matrix to evaluate safety level for each building in UTM campus. The results show that most the buildings in UTM are in good and high safety level, with 65\% of buildings score more than $70 \%$. For buildings was detected with highest score of $95 \%$ of safety level, while 3 buildings score lowest percentage of $53.7 \%$. these results indicated that UTM campus area is a safe area, based on the Safe City Concept. These results can help authorities to use these indicators of Safe City Concept to assess the education campus area safety level.
\end{abstract}

\section{INTRODUCTION}

Safety has become an important concern in urban region, with urbanization process has raised many issues related to quality of life, especially on the safety level of their surrounding area. To encounter this issues, safe city concept has been launched by UN-Habitat with various involvement of agencies, such as United Development Programme (UNDP), United Nation Children's Fund (UNICEF) and United Nations Economic Social and Cultural Organization (UNESCO) to support this initiative (ECU, 2019).

Safe City Programme was introduced in Malaysia in 2004, as a strategy to prevent crime through prevention approach, and this programme is collaboration with Ministry of Housing and Local Government (KPKT) to be implemented in local authority. This initiative consists of 3 strategies and 15 steps to be taken to reduce the crime index in local authorities. Besides Safe City Programme, another initiative is defensible space and crime prevention through environmental design (CPTED) (Hedayati Marzbali et al., 2016). This initiative focused on restructured the physical layout to allow residents of the area to control their surroundings. Other than that, Safe Cities Index also being introduce to urban security and resilience in an interconnected world (The Economist Intelligence Unit, 2019).

Some of these models focus only on crime, other focus on step to improve safety and other model that are broader focus but not specific to safety. Besides that, these models are less emphasis on the aspects of spatial assessment especially the safety level assessment for campus education area.

To assess the safety level of campus area, the aim of this study is to assess the safety level for campus area, based on the safe city concept at Universiti Teknologi Malaysia (UTM) campus.

\section{SAFE CITY INDICATORS}

\subsection{Definitions of Safe City Concept}

To understand better on the Safe City Concept, several definitions from previous studies has been identified, and listed in table 1 below.

\begin{tabular}{|l|l|}
\hline \multicolumn{1}{|c|}{ Definition } & \multicolumn{1}{|c|}{ Author(s) } \\
\hline $\begin{array}{l}\text { Safe City is a city, that by the integration of } \\
\text { technology and natural environment }\end{array}$ & (Lacinák \& \\
increases the effectiveness of processes in & \\
the field of safety, in order to reduce crime & \\
and terror threats, to allow its citizens life in \\
a healthy environment and simple access to \\
healthcare, and to achieve readiness and \\
quick response to threatening or arising \\
emergencies.
\end{tabular}

\footnotetext{
* Corresponding author
} 


\begin{tabular}{|l|l|}
\hline $\begin{array}{l}\text { response plan to major emergency } \\
\text { situations. }\end{array}$ & 2012) \\
\hline $\begin{array}{l}\text { Essential aspects of the safety concept, first } \\
\text { of all, the cross-sectoral definition of } \\
\text { dangerous locations using gender-based } \\
\text { assessment systems, remain outside the } \\
\text { field of view of researchers. }\end{array}$ & \\
\hline $\begin{array}{l}\text { A city can be defined as a safe city as a city } \\
\text { free of violence that destroys property and }\end{array}$ & (Thani et al., \\
lives, free from the threat of destruction due \\
to natural disasters and disasters, \\
$\begin{array}{l}\text { independent of social and moral decline of } \\
\text { the population, and the city also is said to } \\
\text { be safe if the accidents were independently } \\
\text { indoors or outdoors. }\end{array}$ \\
\hline
\end{tabular}

Table 1. Definition of Safe City Concept

From the previous definition, the concept of a safe city requires cooperative involvement from the communities with plan to reduce crime and terror threads, healthy environment, simple access to healthcare, reduce threat from natural disaster, and safe indoor and outdoor for a liveable city.

One way to achieve safe city environment, is via having proper management, planning, implementation and monitoring process. To make a better planning, several models, indicators, and framework has been developed.

\subsection{Models from Previous Studies}

Most of the previous models, or indicators focus on the city, or urban area, and not focusing on the safety level of campus areas. But these models or indicators can become a based for safe city concept for campuses. Table 2 shows the previous studies on the models, indicators, or framework related to safe city concepts.

\begin{tabular}{|c|c|c|}
\hline $\begin{array}{l}\text { Safe City } \\
\text { Concepts }\end{array}$ & Descriptions & $\begin{array}{c}\text { Author } \\
\text { (s) }\end{array}$ \\
\hline $\begin{array}{l}\text { Comprehensive } \\
\text { threat } \\
\text { assessment/ } \\
\text { behavioral } \\
\text { intervention } \\
\text { model }\end{array}$ & $\begin{array}{l}\text { Designed to reduce the } \\
\text { potential risk posed by the } \\
\text { inappropriate, disruptive or } \\
\text { violent behavior of } \\
\text { individuals in university and } \\
\text { campus settings }\end{array}$ & $\begin{array}{l}\text { (Keller } \\
\text { et al., } \\
2011)\end{array}$ \\
\hline $\begin{array}{l}\text { Safe City } \\
\text { Program that } \\
\text { relates to the } \\
\text { tourism industry }\end{array}$ & $\begin{array}{l}\text { The effectiveness of the } 19 \\
\text { crime prevention steps that } \\
\text { applied in Putrajaya since } \\
2004 \text { are evaluated }\end{array}$ & $\begin{array}{l}\text { (Aris- } \\
\text { Anuar et } \\
\text { al., } \\
\text { 2011) }\end{array}$ \\
\hline $\begin{array}{l}\text { The features of } \\
\text { urban areas with } \\
\text { the use of } \\
\text { feminist optics } \\
\text { for the concepts } \\
\text { of a safe city } \\
\text { has been } \\
\text { analyze }\end{array}$ & $\begin{array}{l}\text { Developed gender-sensitive } \\
\text { geo-information maps of } \\
\text { Kharkiv through explication } \\
\text { of the problem of urban } \\
\text { infrastructure security and } \\
\text { also develop a solution for } \\
\text { integrating GIS data of } \\
\text { gender-sensitive maps into } \\
\text { the processes of managing the } \\
\text { content of urban } \\
\text { infrastructure projects and } \\
\text { programs }\end{array}$ & $\begin{array}{l}\text { (Fesenk } \\
\text { o et al., } \\
2017)\end{array}$ \\
\hline
\end{tabular}

\begin{tabular}{|c|c|c|}
\hline $\begin{array}{l}\text { Safe city model } \\
\text { of smart city } \\
\text { that is based on } \\
\text { the safe city } \\
\text { concept }\end{array}$ & $\begin{array}{l}\text { The integration of technology } \\
\text { and natural environment } \\
\text { increases the effectiveness of } \\
\text { processes in the field of } \\
\text { safety, in order to reduce } \\
\text { crime and terror threats, to } \\
\text { allow its citizens life in } \\
\text { healthy environment and } \\
\text { simple access to healthcare }\end{array}$ & $\begin{array}{l}\text { (Laciná } \\
\text { k \& } \\
\text { Ristvej, } \\
\text { 2017) } \\
\text { (Ristvej } \\
\text { et al., } \\
\text { 2020) }\end{array}$ \\
\hline $\begin{array}{l}\text { Safe City } \\
\text { Monitoring } \\
\text { System } \\
\end{array}$ & $\begin{array}{l}\text { GIS web-based application } \\
\text { that develops in aiding in } \\
\text { crime monitoring in Malaysia }\end{array}$ & $\begin{array}{l}\text { (Shamsu } \\
\text { din et } \\
\text { al., n.d.) }\end{array}$ \\
\hline $\begin{array}{l}\text { Assisting the } \\
\text { safe city model } \\
\text { effectiveness } \\
\text { from the } \\
\text { residents' } \\
\text { perspectives }\end{array}$ & $\begin{array}{l}\text { Crime Prevention Through } \\
\text { Environmental Design } \\
\text { (CEPTD) has six main } \\
\text { components including the } \\
\text { territoriality, surveillance, } \\
\text { access control, target } \\
\text { hardening, legitimate activity } \\
\text { support and lastly, image } \\
\text { management }\end{array}$ & $\begin{array}{l}\text { (Shamsu } \\
\text { ddin et } \\
\text { al., } \\
\text { 2013) }\end{array}$ \\
\hline
\end{tabular}

Table 2. Previous studies on the safe city concepts.

These models, or framework of safe city mainly focus on urban city area, or residential area. To access the safety level of campus or educational area, is a little bit tricky, where there's an administration area, residential area (student's college), and other related landscape and design, beside environmental and tourism parts inside the same compact area. There a need to identify and integrated current safe city model with model to assess the safety level, focusing on campus environment.

\subsection{Indicators for Assessing Safety Level of Campus Area}

One of the methods to assess the safety level of campus area, is via having an indicator as a based. Many studies have identified the indicators, and its sub-indicators to assess the safe city model. This model also provides the method of assessment to assess the safe city model. Table 3 shows the indicators that can be used to assess the safety level of campus area based on the safe city concept.

\begin{tabular}{|c|c|c|c|}
\hline 苞 & Sub-Indicators & $\begin{array}{l}\text { Method for } \\
\text { assessment }\end{array}$ & Authors \\
\hline Uี & $\begin{array}{l}\text { - Crime } \\
\text { - Threats }\end{array}$ & $\begin{array}{l}\text { Crime Prevention } \\
\text { Through } \\
\text { Environmental } \\
\text { Design (CPTED) } \\
\text { has been selected as } \\
\text { one of the methods } \\
\text { of crime prevention } \\
\text { initiatives in } \\
\text { Malaysia } \\
\text { The assessment of } \\
\text { the risk of the } \\
\text { potential threats }\end{array}$ & $\begin{array}{l}\text { (Hedayati } \\
\text { Marzbali } \\
\text { et al., } \\
2016 \text {; } \\
\text { Risdiana } \\
\& \\
\text { Susanto, } \\
2019 ; \\
\text { Ristvej et } \\
\text { al., 2020; } \\
\text { Shamsudd } \\
\text { in et al., } \\
\text { 2013) }\end{array}$ \\
\hline
\end{tabular}




\begin{tabular}{|c|c|c|c|}
\hline 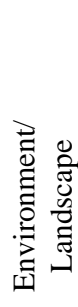 & $\begin{array}{l}\text { - Walkway } \\
\text { - Lighting } \\
\text { - Signage } \\
\text { - Installation of } \\
\text { CCTV } \\
\text { - Provision of } \\
\text { security } \\
\text { alarms }\end{array}$ & $\begin{array}{l}\text { Evaluation of the } \\
\text { importance of crime } \\
\text { prevention steps in } \\
\text { the safe city }\end{array}$ & $\begin{array}{l}\text { (Shamsud } \\
\text { din et al., } \\
2013 \text {; } \\
\text { Thani et } \\
\text { al., 2016) }\end{array}$ \\
\hline 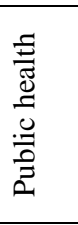 & - Healthcare & $\begin{array}{l}\text { Simple access to } \\
\text { healthcare }\end{array}$ & $\begin{array}{l}\text { (Risdiana } \\
\& \\
\text { Susanto, } \\
2019 ; \\
\text { Ristvej et } \\
\text { al., 2020) }\end{array}$ \\
\hline 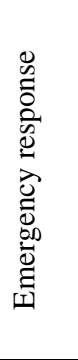 & $\begin{array}{l}\text { - To achieve } \\
\text { readiness and } \\
\text { quick } \\
\text { response to } \\
\text { threatening or } \\
\text { arose } \\
\text { emergencies }\end{array}$ & $\begin{array}{l}\text { Identify the rise of } \\
\text { emergency, to } \\
\text { display actual state } \\
\text { of situation on the } \\
\text { map and to simulate } \\
\text { its progress in real } \\
\text { time or accelerated, } \\
\text { while considering } \\
\text { actual weather } \\
\text { conditions }\end{array}$ & $\begin{array}{l}\text { (Ristvej et } \\
\text { al., 2020) }\end{array}$ \\
\hline
\end{tabular}

Table 3. List of indicators, sub-indicators, and it's descriptions.

Based on the models, indicators, and frameworks from the previous studies, the models, indicators and frameworks are indirectly related to each other which is more to safety and crime. Via having geospatial information and undergo spatial analysis; this model can be enhanced to assist the locations of each event or indicators that can be used to assess the safety level. Table 4 shows the indicators and sub-indicators that can assess the campus's safety level, with integration of geospatial information and analysis.

\begin{tabular}{|c|c|}
\hline Indicators & Sub-indicators \\
\hline Crime & - Number of Crime \\
\hline Environment & $\begin{array}{ll}\text { - } & \text { Walkway } \\
\text { - } & \text { Lighting } \\
\text { - } & \text { Signage } \\
\text { - } & \text { Installation of CCTV } \\
\text { - } & \text { Provision of security alarms }\end{array}$ \\
\hline Public Health & - Clinic or Health Centre \\
\hline $\begin{array}{l}\text { Emergency } \\
\text { response }\end{array}$ & $\begin{array}{ll}\text { - } & \text { Police station } \\
\text { - } & \text { Fire station }\end{array}$ \\
\hline
\end{tabular}

Table 4. Indicators and sub-indicators to assess safety level, via integrating spatial information.

The indicators consist of 4 main indicators; (1) Crime, (2) Environment, (3) Public Health and (4) Emergency Response. The indicators for crime focus on number of crimes in the campus. The indicators of environment focus on assessment on the existence of walkway, lighting in the area, signage, CCTV installation, and the security alarms for the area. For Public Health indicators, it focusses only on the distance between the building with the Health Centre inside and outside campuses. And for Emergency response indicators, it consists of distance to police station, fire station or campus's security division.

\section{RESEARCH METHODOLOGY}

In order to assess the safety level of the campus, this study using Analytic Hierarchy Process (AHP). This being done via determining the indicators using weighted criteria, that evaluates a set of choices against a set of weighted factors. In this study, it consists of 3 main phases, (1) identifying the Safe City Concept from previous studies, (2) integrating the indicators from previous studies into indicators for safety level for campus, and (3) assessment of the safety level.

\subsection{Identifying Safe City Concept}

The first phase is to study and identify the previous model, framework or indicators that related to Safe City Concept. From previous studies, 5 main model/indicators were identified, which is Safer Cities Programme, Safe City Program in Putrajaya Malaysia, Safe City and Community Safety of Safe City, Assessment model of threats on college campus, and Crime Prevention and perception of safety in campus.

From these model or indicators, several indicators and subindicators was identified as listed in Table 3.

\subsection{Integrating Safe City Indicators for Campus}

The listed indicators and sub-indicators that was identified in the previous studies in table 3 then being integrated with spatial information and analysis. The final indicators and sub-indicators that being used in this study then being listed in table 5 . The indicators and sub-indicators were integrated with spatial information, the condition of each sub-indicators, and the score for each condition. Table 5 shows the indicators, sub-indicators, the conditions for sub-indicators, and the score related for each condition.

Based on the indicators and sub-indicators, the next part of second phase is data collection. Data collected in this study is from various sources. For data of Crime (number of cases), this data was collected from Security Department, UTM. The data given is crime data from 2020, and the data is not in digital form, and need data processing and clean-up. Data of CCTV area also being given by Security Department, UTM. Figure 1 shows the data given by UTM's Security Department. Other data such as location of Health Centre, Police Station, and Fire Station was cross-checked with satellite and attribute data that self-collected.

\begin{tabular}{|c|c|c|c|}
\hline Indicators & $\begin{array}{c}\text { Sub- } \\
\text { indicator }\end{array}$ & Condition & Score \\
\hline \multirow[t]{6}{*}{ Crime } & \multicolumn{3}{|c|}{ (Number of cases) } \\
\hline & \multirow[t]{5}{*}{ Crime } & Well below average & 5 \\
\hline & & Below average & 4 \\
\hline & & Average & 3 \\
\hline & & Above average & 2 \\
\hline & & Well above average & 1 \\
\hline \multirow[t]{11}{*}{ Environment } & \multicolumn{3}{|c|}{ (Item Present) } \\
\hline & \multirow[t]{2}{*}{ Walkway } & Yes & 1 \\
\hline & & No & 0 \\
\hline & \multirow[t]{2}{*}{ Lighting } & Yes & 1 \\
\hline & & No & 0 \\
\hline & \multirow[t]{2}{*}{ Signage } & Yes & 1 \\
\hline & & $\mathrm{No}$ & 0 \\
\hline & \multirow[t]{2}{*}{ CCTV } & Yes & 1 \\
\hline & & No & 0 \\
\hline & \multirow{2}{*}{$\begin{array}{c}\text { Fire } \\
\text { alarms }\end{array}$} & Yes & 1 \\
\hline & & No & 0 \\
\hline
\end{tabular}




\begin{tabular}{|c|c|c|c|}
\hline \multirow{4}{*}{$\begin{array}{l}\text { Public } \\
\text { Health }\end{array}$} & \multicolumn{3}{|c|}{ (Distance) } \\
\hline & \multirow{3}{*}{$\begin{array}{c}\text { Distance } \\
\text { to Health } \\
\text { Care }\end{array}$} & $0-800 \mathrm{~m}$ & 3 \\
\hline & & $801-1499 m$ & 2 \\
\hline & & $>1500$ & 1 \\
\hline \multirow{7}{*}{$\begin{array}{c}\text { Emergency } \\
\text { Response }\end{array}$} & \multicolumn{3}{|c|}{ (Distance) } \\
\hline & \multirow{3}{*}{$\begin{array}{l}\text { Police } \\
\text { Station }\end{array}$} & $0-800 \mathrm{~m}$ & 3 \\
\hline & & 801-1499m & 2 \\
\hline & & $>1500$ & 1 \\
\hline & \multirow{3}{*}{$\begin{array}{l}\text { Fire } \\
\text { Station }\end{array}$} & $0-800 \mathrm{~m}$ & 3 \\
\hline & & $801-1499 m$ & 2 \\
\hline & & $>1500$ & 1 \\
\hline
\end{tabular}

Table 5. Indicators, sub-indicators, condition and scoring to assess the safety level for campus.

Besides that, data for Environment's indicators was collected inside UTM, self-collected. This included the walkway, lighting and signage.

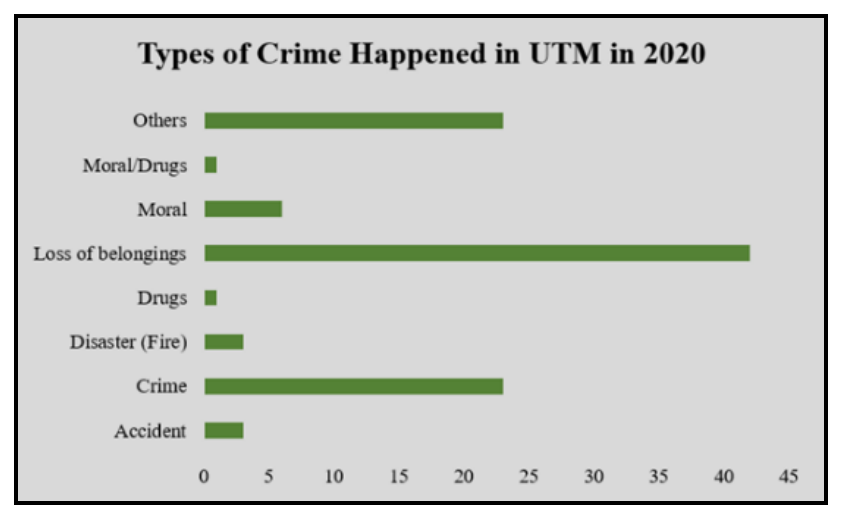

Figure 1. Graph of Types of Crime Happened in UTM in 2020.

\subsection{Assessment of the Campus Safety Level}

In this study, the safety level for campus areas is determined by using the weighted criteria. The weighted criteria matrix is a valuable decision-making tool that is used to evaluate program alternatives based on specific evaluation criteria weighted by importance. By evaluating alternatives based on their performance with respect to individual criteria, a value for the alternative can be identified. Table 6 shows the calculation on the weighted criteria matrix used in this study.

\begin{tabular}{|c|c|c|c|c|c|c|c|}
\hline Criteria & 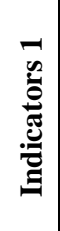 & $\begin{array}{l}\vec{E} \\
\overrightarrow{000} \\
\vec{E}\end{array}$ & 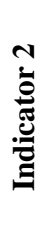 & $\begin{array}{l}\overrightarrow{\vec{E}} \\
\frac{000}{\vec{\theta}} \\
\overrightarrow{3}\end{array}$ & हैं & 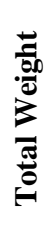 & \\
\hline Choice A & & & & & & & \\
\hline Choice B & & & & & & & \\
\hline Choice C & & & & & & & \\
\hline Total Score & & & & & & & \\
\hline Total Max Score & & & & & & & \\
\hline
\end{tabular}

Table 6. Matrix to calculate the total weight and safety level in this study.

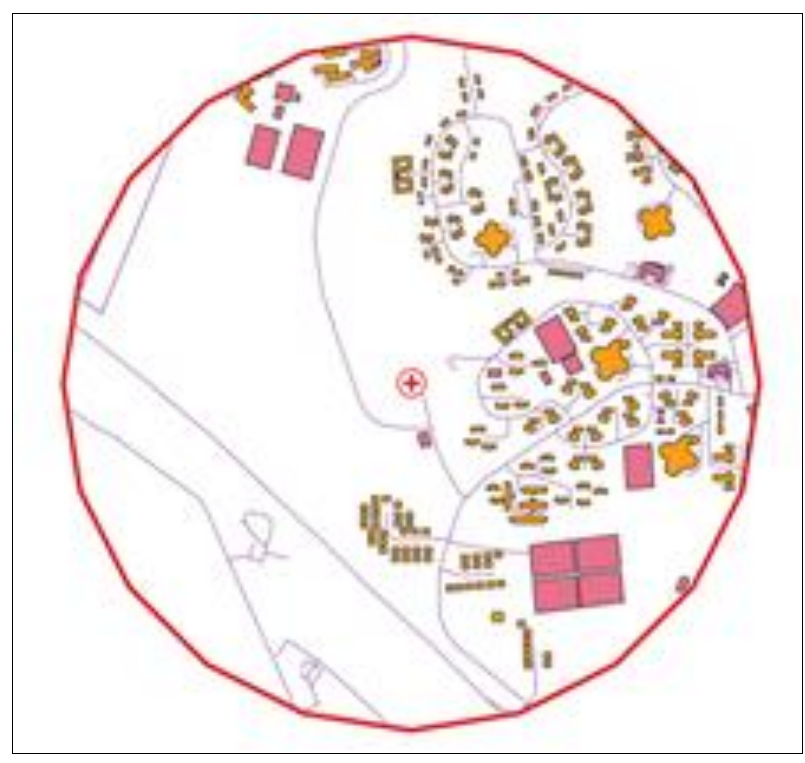

Figure 2. Example of buffer analysis (distance to UTM Health Centre)

The criteria of each factor are weighted relative to their perceived importance and each factor is scored against each criterion. To identify and acquire the scoring of the indicators in order to decide the safety level, several spatial analyses need to be performed based on the condition of each sub-indicator. Figure 2 shows example of buffer Analysis of the faculty, college, facilities \& others less than 800m from UTM Health Centre.

\section{RESULTS AND DISCUSSIONS}

\subsection{Indicators Analysis}

The results from the analysis are according to the campus safety level, that is Crime, Environment, Public Health, and Emergency Response. The results are present in the table 7 and figure 3 to figure 8

4.1.1 Crime Indicator: Figure 3 shows the results of analysis for crime indicator. From the analysis, the highest percentage for this Crime Indicator based on faculties, colleges, facilities \& others are $100 \%$. Meanwhile, the least percentage of safety level for this indicator is $20 \%$ for C_ 4 which are Kolej Datin Sri Endon (KDSE) and the college which obtain $40 \%$ of Crime Indicator is C_5 which is Kolej Dato Onn Jaafar (KDOJ). The scores are based on the total numbers of crime that occurred in that particular faculty, college, facilities \& others. Most of the results have the highest score which is $100 \%$ that indicates the locations are safer compared to others that received low percentage.

4.1.2 Environment Indicator: For Environment indicator analysis, there are 5 sub-indicators being analyse. From the analysis, the highest percentage for this Environment/Landscape Indicator based on faculties, colleges, facilities \& others are $80 \%$. Meanwhile, the least percentage of safety level for this indicator is $20 \%$. The indicators are based on the presence of walkway, lighting, signage, CCTV and fire alarms for that particular location. Figure 4 shows the results of this analysis. 
4.1.3 Public Health Indicator: Figure 5 shows the results from the analysis for Public Health Indicator. There only 1 subindicators, which is distance from building to the nearest UTM's Health Centre. From the analysis, the highest percentage for this Public Health Indicator based on faculties, colleges, facilities \& others are $100 \%$. Meanwhile, the least percentage of safety level for this indicator is $33.33 \%$. The scores are based on the distance from Health Centre to the particular location. The highest percentage shows the distance from the location is less than $800 \mathrm{~m}$ to Health Centre.
4.1.4 Emergency Response Indicator: For Emergency response indicator, there are 2 sub-indicators, which is the distance from police station, and distance from fire station. From the analysis, there is an equal score for all the faculty, college, facilities \& others located in UTM campus where the score is $33.33 \%$ for safety level based on Emergency Response Indicator. This is because both the Police Station and Fire Station are located outside the campus area which is in Taman Universiti. Therefore, the distance from particular locations to both stations are more than $1500 \mathrm{~m}$ hence the percentage for this indicator is low. Figure 6 shows the results of this indicator.

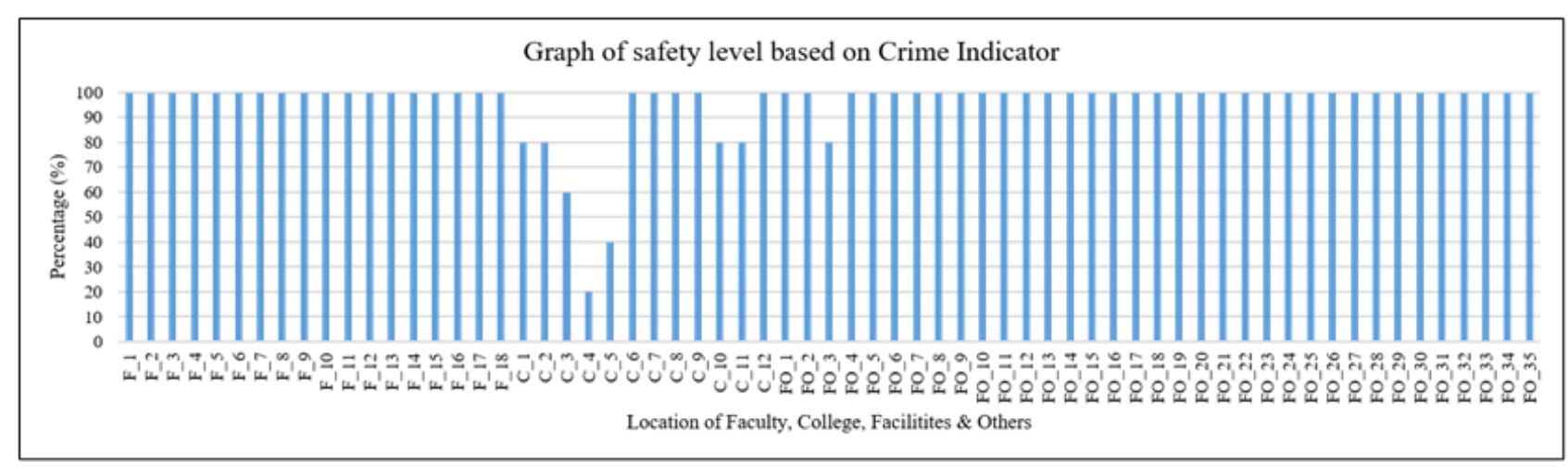

Figure 3. Results of Crime Indicator.

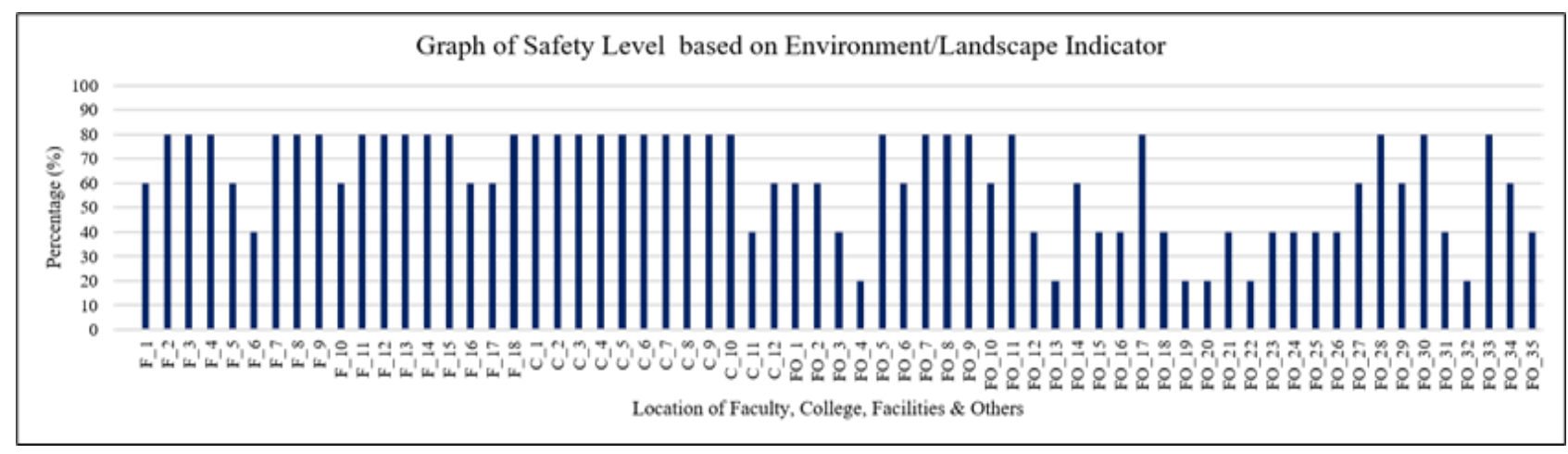

Figure 4. Result of analysis for Environment Indicator.

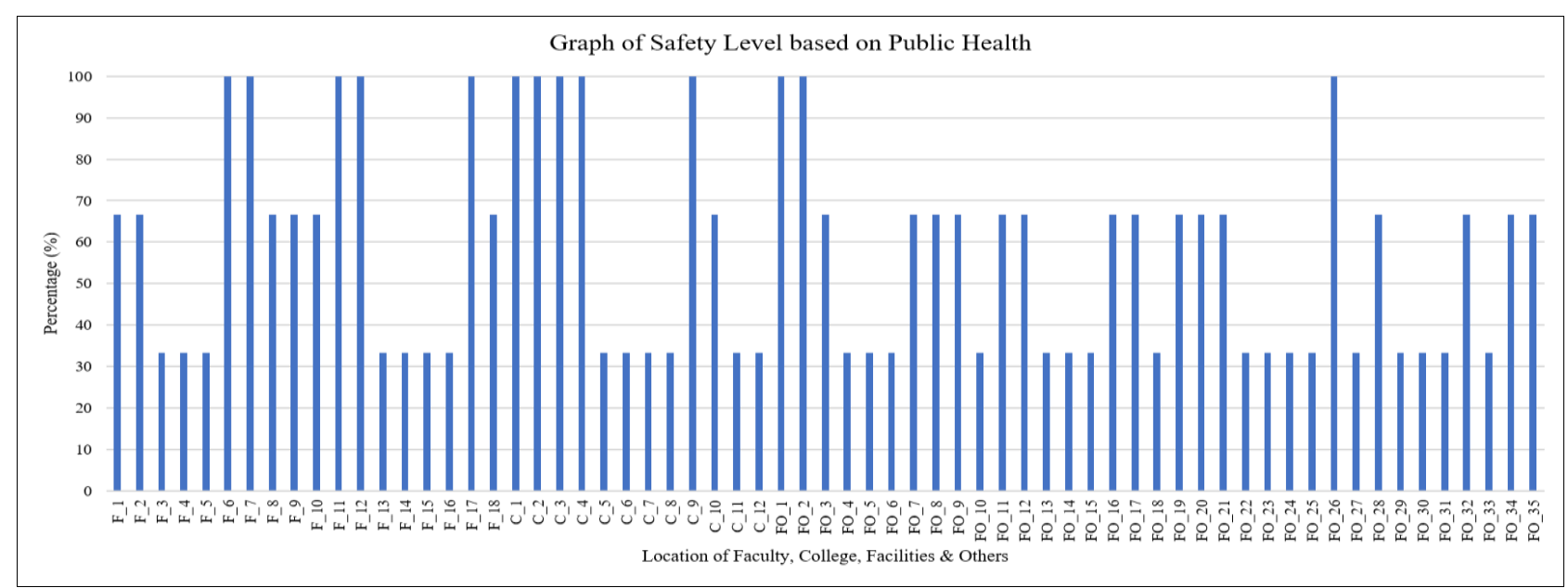

Figure 5. Result of analysis for Public Health Indicator. 


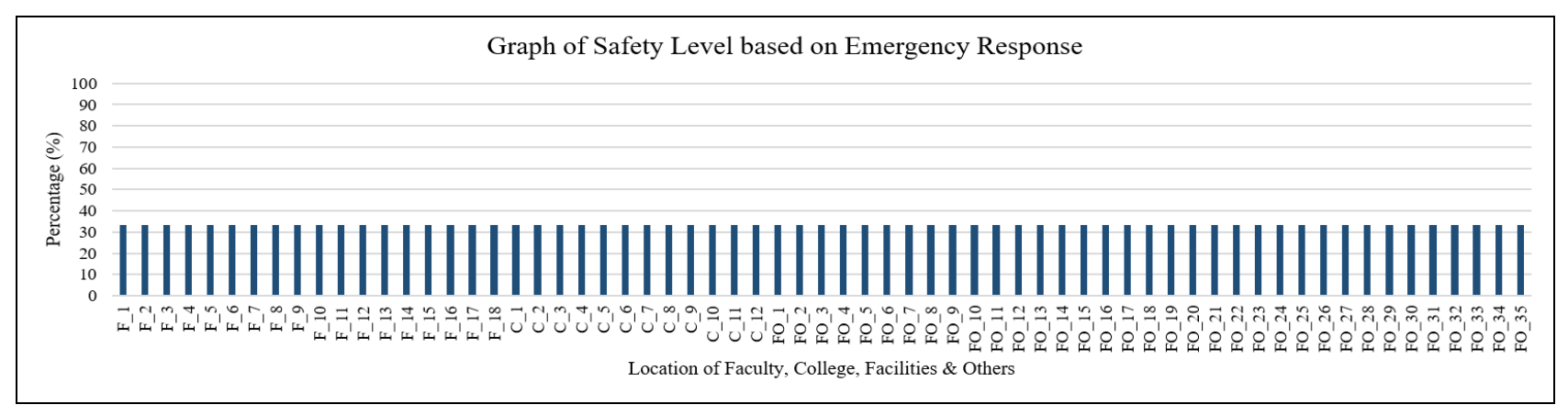

Figure 6. Result of Analysis for Emergency Response Indicator.

\begin{tabular}{|c|c|c|c|c|c|c|c|c|c|c|c|c|c|c|c|c|}
\hline \multirow{3}{*}{ ID } & \multirow{3}{*}{ Location } & \multicolumn{13}{|c|}{ Score } & \multirow{3}{*}{ Total } & \multirow{3}{*}{ 党造 } \\
\hline & & \multirow{2}{*}{$\begin{array}{l}\mathrm{C} \\
\mathrm{C}\end{array}$} & \multirow[t]{2}{*}{ TW } & \multicolumn{5}{|c|}{ EL } & \multirow[t]{2}{*}{ TW } & \multirow{2}{*}{$\begin{array}{c}\text { PH } \\
\text { PKU }\end{array}$} & \multirow[t]{2}{*}{ TW } & \multicolumn{2}{|c|}{ ER } & \multirow[t]{2}{*}{ TW } & & \\
\hline & & & & W & $\mathbf{L}$ & $\mathbf{S}$ & $\begin{array}{l}\text { CC } \\
\text { TV }\end{array}$ & FA & & & & $\begin{array}{l}\mathbf{P} \\
\mathbf{S}\end{array}$ & $\begin{array}{l}\mathbf{F} \\
\mathbf{S}\end{array}$ & & & \\
\hline F_1 & $\begin{array}{c}\text { Akademi } \\
\text { Bahasa }\end{array}$ & 5 & 0.30 & 1 & 1 & 0 & 0 & 1 & 0.21 & 2 & 0.133 & 1 & 1 & 0.1 & 0.743 & 74.30 \\
\hline F_2 & FABU & 5 & 0.30 & 1 & 1 & 0 & 1 & 1 & 0.35 & 2 & 0.133 & 1 & 1 & 0.1 & 0.883 & 88.30 \\
\hline F_3 & $\begin{array}{l}\text { FBME } \\
\text { T02 }\end{array}$ & 5 & 0.30 & 1 & 1 & 0 & 1 & 1 & 0.35 & 1 & 0.067 & 1 & 1 & 0.1 & 0.817 & 81.70 \\
\hline F_4 & $\begin{array}{l}\text { FBME } \\
\text { V01 }\end{array}$ & 5 & 0.30 & 1 & 1 & 0 & 1 & 1 & 0.35 & 1 & 0.067 & 1 & 1 & 0.1 & 0.817 & 81.70 \\
\hline F_5 & $\begin{array}{c}\text { FGHT } \\
\text { T06 }\end{array}$ & 5 & 0.30 & 1 & 1 & 0 & 0 & 1 & 0.21 & 1 & 0.067 & 1 & 1 & 0.1 & 0.677 & 67.70 \\
\hline F_6 & FK & 5 & 0.30 & 0 & 1 & 0 & 1 & 0 & 0.14 & 3 & 0.200 & 1 & 1 & 0.1 & 0.740 & 74.00 \\
\hline F_7 & FKA & 5 & 0.30 & 1 & 1 & 0 & 1 & 1 & 0.35 & 3 & 0.200 & 1 & 1 & 0.1 & 0.950 & 95.00 \\
\hline F_8 & FKE & 5 & 0.30 & 1 & 1 & 0 & 1 & 1 & 0.35 & 2 & 0.133 & 1 & 1 & 0.1 & 0.883 & 88.30 \\
\hline F_9 & FKM & 5 & 0.30 & 1 & 1 & 0 & 1 & 1 & 0.35 & 2 & 0.133 & 1 & 1 & 0.1 & 0.883 & 88.30 \\
\hline F_10 & FKT & 5 & 0.30 & 1 & 1 & 0 & 0 & 1 & 0.21 & 2 & 0.133 & 1 & 1 & 0.1 & 0.743 & 74.30 \\
\hline F_11 & $\mathrm{FP}$ & 5 & 0.30 & 1 & 1 & 0 & 1 & 1 & 0.35 & 3 & 0.200 & 1 & 1 & 0.1 & 0.950 & 95.00 \\
\hline F_12 & FS & 5 & 0.30 & 1 & 1 & 0 & 1 & 1 & 0.35 & 3 & 0.200 & 1 & 1 & 0.1 & 0.950 & 95.00 \\
\hline F_13 & FS T05 & 5 & 0.30 & 1 & 1 & 0 & 1 & 1 & 0.35 & 1 & 0.067 & 1 & 1 & 0.1 & 0.817 & 81.70 \\
\hline F_14 & FSSK T08 & 5 & 0.30 & 1 & 1 & 0 & 1 & 1 & 0.35 & 1 & 0.067 & 1 & 1 & 0.1 & 0.817 & 81.70 \\
\hline F_15 & FTI T07 & 5 & 0.30 & 1 & 1 & 0 & 1 & 1 & 0.35 & 1 & 0.067 & 1 & 1 & 0.1 & 0.817 & 81.70 \\
\hline F_16 & $\begin{array}{c}\text { Makmal } \\
\text { Penyelidik } \\
\text { an T03 } \\
\end{array}$ & 5 & 0.30 & 0 & 1 & 0 & 1 & 1 & 0.21 & 1 & 0.067 & 1 & 1 & 0.1 & 0.677 & 67.70 \\
\hline F_17 & $\begin{array}{c}\text { Pusat } \\
\text { Kokurikul } \\
\text { um } \\
\end{array}$ & 5 & 0.30 & 1 & 1 & 0 & 1 & 0 & 0.21 & 3 & 0.200 & 1 & 1 & 0.1 & 0.810 & 81.00 \\
\hline F_18 & SPS & 5 & 0.30 & 1 & 1 & 0 & 1 & 1 & 0.35 & 2 & 0.133 & 1 & 1 & 0.1 & 0.883 & 88.30 \\
\hline C_1 & $\begin{array}{c}\text { Kolej } \\
\text { Rahman } \\
\text { Putra } \\
\end{array}$ & 4 & 0.24 & 1 & 1 & 0 & 1 & 1 & 0.35 & 3 & 0.200 & 1 & 1 & 0.1 & 0.890 & 89.00 \\
\hline C_2 & $\begin{array}{l}\text { Kolej Tun } \\
\text { Fatimah }\end{array}$ & 4 & 0.24 & 1 & 1 & 0 & 1 & 1 & 0.35 & 3 & 0.200 & 1 & 1 & 0.1 & 0.890 & 89.00 \\
\hline C_3 & $\begin{array}{c}\text { Kolej Tun } \\
\text { Razak }\end{array}$ & 3 & 0.18 & 1 & 1 & 0 & 1 & 1 & 0.35 & 3 & 0.200 & 1 & 1 & 0.1 & 0.830 & 83.00 \\
\hline C_4 & $\begin{array}{c}\text { Kolej } \\
\text { Datin Seri } \\
\text { Endon }\end{array}$ & 1 & 0.06 & 1 & 1 & 0 & 1 & 1 & 0.35 & 3 & 0.200 & 1 & 1 & 0.1 & 0.710 & 71.00 \\
\hline C_5 & $\begin{array}{c}\text { Kolej } \\
\text { Dato Onn } \\
\text { Jaafar } \\
\end{array}$ & 2 & 0.12 & 1 & 1 & 0 & 1 & 1 & 0.35 & 1 & 0.067 & 1 & 1 & 0.1 & 0.637 & 63.70 \\
\hline C_6 & $\begin{array}{c}\text { Kolej } \\
\text { Tunku } \\
\text { Cancelor } \\
\end{array}$ & 5 & 0.30 & 1 & 1 & 0 & 1 & 1 & 0.35 & 1 & 0.067 & 1 & 1 & 0.1 & 0.817 & 81.70 \\
\hline C_7 & $\begin{array}{c}\text { Kolej } \\
\text { Perdana }\end{array}$ & 5 & 0.30 & 1 & 1 & 0 & 1 & 1 & 0.35 & 1 & 0.067 & 1 & 1 & 0.1 & 0.817 & 81.70 \\
\hline C_8 & $\begin{array}{l}\text { Kolej } \\
9 \& 10\end{array}$ & 5 & 0.30 & 1 & 1 & 0 & 1 & 1 & 0.35 & 1 & 0.067 & 1 & 1 & 0.1 & 0.817 & 81.70 \\
\hline
\end{tabular}




\begin{tabular}{|c|c|c|c|c|c|c|c|c|c|c|c|c|c|c|c|c|}
\hline C_9 & $\begin{array}{c}\text { Kolej Tun } \\
\text { Hussein } \\
\text { Onn }\end{array}$ & 5 & 0.30 & 1 & 1 & 0 & 1 & 1 & 0.35 & 3 & 0.200 & 1 & 1 & 0.1 & 0.950 & 95.00 \\
\hline C_10 & $\begin{array}{l}\text { Kolej Tun } \\
\text { Dr. Ismail }\end{array}$ & 4 & 0.24 & 1 & 1 & 0 & 1 & 1 & 0.35 & 2 & 0.133 & 1 & 1 & 0.1 & 0.823 & 82.30 \\
\hline C_11 & $\begin{array}{c}\text { KLG } \\
\text { Campus } \\
\text { Residence }\end{array}$ & 4 & 0.24 & 1 & 1 & 0 & 0 & 0 & 0.14 & 1 & 0.067 & 1 & 1 & 0.1 & 0.547 & 54.70 \\
\hline C_12 & $\begin{array}{l}\text { Scholars } \\
\text { Inn }\end{array}$ & 5 & 0.30 & 1 & 1 & 0 & 1 & 0 & 0.21 & 1 & 0.067 & 1 & 1 & 0.1 & 0.677 & $\begin{array}{c}67.70 \\
0\end{array}$ \\
\hline FO_1 & $\begin{array}{c}\text { Arked } \\
\text { Cengal }\end{array}$ & 5 & 0.30 & 0 & 1 & 0 & 0 & 1 & 0.14 & 3 & 0.200 & 1 & 1 & 0.1 & 0.740 & 74.00 \\
\hline FO_2 & $\begin{array}{c}\text { Arked } \\
\text { Meranti }\end{array}$ & 5 & 0.30 & 0 & 1 & 0 & 1 & 1 & 0.21 & 3 & 0.200 & 1 & 1 & 0.1 & 0.810 & 81.00 \\
\hline FO_3 & $\begin{array}{c}\text { Bahagian } \\
\text { Keselamat } \\
\text { an } \\
\end{array}$ & 4 & 0.24 & 0 & 1 & 0 & 0 & 1 & 0.14 & 2 & 0.133 & 1 & 1 & 0.1 & 0.613 & 61.30 \\
\hline FO_4 & $\begin{array}{c}\text { Balai } \\
\text { Cerapan }\end{array}$ & 5 & 0.30 & 0 & 0 & 0 & 1 & 0 & 0.07 & 1 & 0.067 & 1 & 1 & 0.1 & 0.537 & 53.70 \\
\hline FO_5 & $\begin{array}{c}\text { Bangunan } \\
\text { Canselori }\end{array}$ & 5 & 0.30 & 1 & 1 & 0 & 1 & 1 & 0.35 & 1 & 0.067 & 1 & 1 & 0.1 & 0.817 & 81.70 \\
\hline FO_6 & $\begin{array}{c}\text { C - FIRST } \\
\text { S44 S45 }\end{array}$ & 5 & 0.30 & 1 & 1 & 0 & 0 & 1 & 0.21 & 1 & 0.067 & 1 & 1 & 0.1 & 0.677 & 67.70 \\
\hline FO_7 & CICT D07 & 5 & 0.30 & 1 & 1 & 0 & 1 & 1 & 0.35 & 2 & 0.133 & 1 & 1 & 0.1 & 0.883 & 88.30 \\
\hline FO_8 & $\begin{array}{l}\text { Dewan } \\
\text { L50 }\end{array}$ & 5 & 0.30 & 1 & 1 & 0 & 1 & 1 & 0.35 & 2 & 0.133 & 1 & 1 & 0.1 & 0.883 & 88.30 \\
\hline FO_9 & $\begin{array}{c}\text { Dewan } \\
\text { N24 }\end{array}$ & 5 & 0.30 & 1 & 1 & 0 & 1 & 1 & 0.35 & 2 & 0.133 & 1 & 1 & 0.1 & 0.883 & 88.30 \\
\hline $\begin{array}{c}\mathrm{FO}_{-1} \\
0\end{array}$ & $\begin{array}{c}\text { Dewan } \\
\text { P19 }\end{array}$ & 5 & 0.30 & 0 & 1 & 0 & 1 & 1 & 0.21 & 1 & 0.067 & 1 & 1 & 0.1 & 0.677 & 67.70 \\
\hline $\begin{array}{c}\mathrm{FO}_{1} 1 \\
1\end{array}$ & $\begin{array}{l}\text { Dewan } \\
\text { Sultan } \\
\text { Iskandar }\end{array}$ & 5 & 0.30 & 1 & 1 & 0 & 1 & 1 & 0.35 & 2 & 0.133 & 1 & 1 & 0.1 & 0.883 & 88.30 \\
\hline $\mathrm{FO}_{2} 1$ & JHB & 5 & 0.30 & 0 & 1 & 0 & 0 & 1 & 0.14 & 2 & 0.133 & 1 & 1 & 0.1 & 0.673 & 67.30 \\
\hline $\begin{array}{c}\mathrm{FO}_{3} 1 \\
\end{array}$ & $\begin{array}{c}\text { Kolam } \\
\text { Renang } \\
\text { U1a }\end{array}$ & 5 & 0.30 & 0 & 0 & 0 & 0 & 1 & 0.07 & 1 & 0.067 & 1 & 1 & 0.1 & 0.537 & 53.70 \\
\hline $\mathrm{FO}_{4} 1$ & $\begin{array}{c}\text { Kompleks } \\
\text { Sukan } \\
\text { U01 }\end{array}$ & 5 & 0.30 & 1 & 1 & 0 & 0 & 1 & 0.21 & 1 & 0.067 & 1 & 1 & 0.1 & 0.677 & 67.70 \\
\hline $\mathrm{FO}_{5}{ }^{1}$ & $\begin{array}{c}\text { KOR } \\
\text { SUKSIS } \\
\text { U10 }\end{array}$ & 5 & 0.30 & 0 & 1 & 0 & 0 & 1 & 0.14 & 1 & 0.067 & 1 & 1 & 0.1 & 0.607 & 60.70 \\
\hline$\underset{6}{\mathrm{FO}_{6} 1}$ & $\begin{array}{c}\text { Markas } \\
\text { Palapes } \\
\text { M44 }\end{array}$ & 5 & 0.30 & 0 & 1 & 0 & 0 & 1 & 0.14 & 2 & 0.133 & 1 & 1 & 0.1 & 0.673 & 67.30 \\
\hline $\begin{array}{c}\mathrm{FO}_{7} 1 \\
\end{array}$ & Masjid & 5 & 0.30 & 1 & 1 & 0 & 1 & 1 & 0.35 & 2 & 0.133 & 1 & 1 & 0.1 & 0.883 & 88.30 \\
\hline $\begin{array}{c}\mathrm{FO}_{-1} \\
8\end{array}$ & $\begin{array}{l}\text { Padang } \\
\text { Kawad }\end{array}$ & 5 & 0.30 & 0 & 1 & 0 & 1 & 0 & 0.14 & 1 & 0.067 & 1 & 1 & 0.1 & 0.607 & 60.70 \\
\hline $\begin{array}{c}\mathrm{FO}_{9} 1 \\
\end{array}$ & $\begin{array}{c}\text { Pejabat } \\
\text { OSHE } \\
\text { M41 }\end{array}$ & 5 & 0.30 & 1 & 1 & 0 & 0 & 1 & 0.21 & 2 & 0.133 & 1 & 1 & 0.1 & 0.743 & 74.30 \\
\hline $\begin{array}{c}\mathrm{FO}_{0} 2 \\
0\end{array}$ & $\begin{array}{c}\text { Pertahana } \\
\text { n Awam } \\
\text { N25 }\end{array}$ & 5 & 0.30 & 0 & 1 & 0 & 0 & 0 & 0.07 & 2 & 0.133 & 1 & 1 & 0.1 & 0.603 & 60.30 \\
\hline $\begin{array}{c}\mathrm{FO}_{1} 2 \\
1\end{array}$ & Pintu 1 & 5 & 0.30 & 0 & 1 & 0 & 1 & 0 & 0.14 & 2 & 0.133 & 1 & 1 & 0.1 & 0.673 & 67.30 \\
\hline $\begin{array}{c}\mathrm{FO}_{2} 2 \\
\end{array}$ & Pintu 2 & 5 & 0.30 & 0 & 1 & 0 & 0 & 0 & 0.07 & 1 & 0.067 & 1 & 1 & 0.1 & 0.537 & 53.70 \\
\hline $\mathrm{FO}_{3} 2$ & Pintu 3 & 5 & 0.30 & 0 & 1 & 0 & 1 & 0 & 0.14 & 1 & 0.067 & 1 & 1 & 0.1 & 0.607 & 60.70 \\
\hline $\begin{array}{c}\mathrm{FO}_{4} 2 \\
\end{array}$ & Pintu 4 & 4 & 0.24 & 0 & 1 & 0 & 1 & 0 & 0.14 & 1 & 0.067 & 1 & 1 & 0.1 & 0.547 & 54.70 \\
\hline
\end{tabular}




\begin{tabular}{|c|c|c|c|c|c|c|c|c|c|c|c|c|c|c|c|c|}
\hline $\mathrm{FO}_{5}{ }^{2}$ & Pintu 5 & 5 & 0.30 & 0 & 1 & 0 & 1 & 0 & 0.14 & 1 & 0.067 & 1 & 1 & 0.1 & 0.607 & 60.70 \\
\hline $\begin{array}{c}\mathrm{FO}_{6} 2 \\
\end{array}$ & PKU & 5 & 0.30 & 0 & 1 & 0 & 0 & 1 & 0.14 & 3 & 0.200 & 1 & 1 & 0.1 & 0.740 & 74.00 \\
\hline $\begin{array}{c}\mathrm{FO}_{7} 2 \\
\end{array}$ & PRZS & 5 & 0.30 & 0 & 1 & 0 & 1 & 1 & 0.21 & 1 & 0.067 & 1 & 1 & 0.1 & 0.677 & 67.70 \\
\hline $\begin{array}{c}\mathrm{FO}_{8} 2 \\
8\end{array}$ & PSZ & 5 & 0.30 & 1 & 1 & 0 & 1 & 1 & 0.35 & 2 & 0.133 & 1 & 1 & 0.1 & 0.883 & 88.30 \\
\hline $\begin{array}{c}\text { FO_2 } \\
9\end{array}$ & $\begin{array}{c}\text { Pusat } \\
\text { Kaunselin } \\
\text { g } \\
\end{array}$ & 5 & 0.30 & 1 & 1 & 0 & 0 & 1 & 0.21 & 1 & 0.067 & 1 & 1 & 0.1 & 0.677 & 67.70 \\
\hline $\begin{array}{c}\mathrm{FO}_{0} 3 \\
0\end{array}$ & $\begin{array}{c}\text { Pusat } \\
\text { Latihan } \\
\text { UTM } \\
\text { XB4 }\end{array}$ & 5 & 0.30 & 1 & 1 & 0 & 1 & 1 & 0.35 & 1 & 0.067 & 1 & 1 & 0.1 & 0.817 & 81.70 \\
\hline $\begin{array}{c}\mathrm{FO}_{1} 3 \\
1\end{array}$ & $\begin{array}{l}\text { Rumah } \\
\text { Alumni }\end{array}$ & 5 & 0.30 & 0 & 1 & 0 & 1 & 0 & 0.14 & 1 & 0.067 & 1 & 1 & 0.1 & 0.607 & 60.70 \\
\hline $\begin{array}{c}\mathrm{FO}_{2} 3 \\
2\end{array}$ & $\begin{array}{l}\text { Rumah } \\
\text { Tropika }\end{array}$ & 5 & 0.30 & 1 & 0 & 0 & 0 & 0 & 0.07 & 2 & 0.133 & 1 & 1 & 0.1 & 0.603 & 60.30 \\
\hline $\begin{array}{c}\mathrm{FO}_{3} 3 \\
3\end{array}$ & $\begin{array}{c}\text { Stadium } \\
\text { UTM U1b }\end{array}$ & 5 & 0.30 & 1 & 1 & 0 & 1 & 1 & 0.35 & 1 & 0.067 & 1 & 1 & 0.1 & 0.817 & 81.70 \\
\hline$\underset{4}{\mathrm{FO}_{4} 3}$ & $\begin{array}{c}\text { Student } \\
\text { Union } \\
\text { Building }\end{array}$ & 5 & 0.30 & 1 & 1 & 0 & 0 & 1 & 0.21 & 2 & 0.133 & 1 & 1 & 0.1 & 0.743 & 74.30 \\
\hline \multirow[t]{3}{*}{$\begin{array}{c}\mathrm{FO}_{5} 3 \\
\end{array}$} & $\begin{array}{c}\text { UTM CC } \\
\text { L51 }\end{array}$ & 5 & 0.30 & 1 & 0 & 0 & 0 & 1 & 0.14 & 2 & 0.133 & 1 & 1 & 0.1 & 0.673 & 67.30 \\
\hline & $\begin{array}{c}\text { Total } \\
\text { Score } \\
\end{array}$ & & & & & & & & & & & & & & $\begin{array}{c}48.87 \\
6 \\
\end{array}$ & \\
\hline & $\begin{array}{c}\text { Total } \\
\text { Max } \\
\text { Score } \\
\end{array}$ & 5 & & 1 & 1 & 1 & 1 & 1 & & 3 & & 3 & 3 & & 19 & \\
\hline
\end{tabular}

*Notes:

Table 7. Results of Safety Level Assessment analysis for Building in UTM Campus

\section{$\mathrm{C}$ : Crime}

CCTV: $C C T V$

EL: Environment/Landscape

ER: Emergency Response

FA: Fire Alarms

FS: Fire Station

L: Lighting

PKU: Pusat Kesihatan Universiti

PS: Police Station

S: Signage

TW: Total Weight

W: Walkway

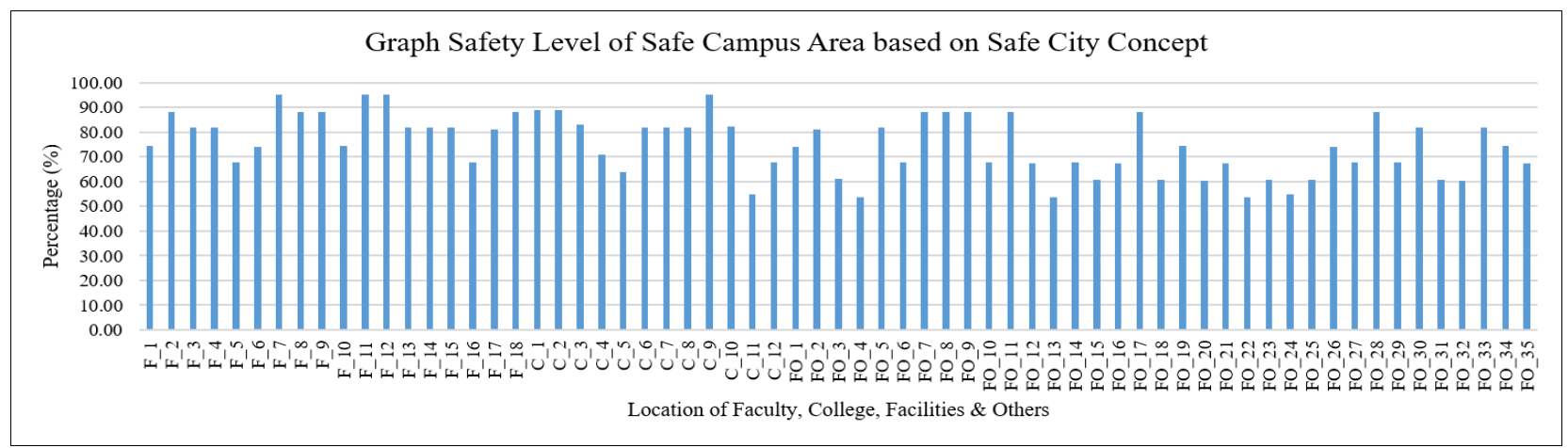

Figure 8. Graph of percentage of Safety Level for UTM Campus. 
4.1.5 Overall Indicators Analysis: The overall analysis is a combination of all indicators analysis form this study. From the analysis, it shows that, most of the building in UTM Campus have high safety level, with the $35 \%$ of the building score 70 $80 \%$ safety level, $21 \%$ are between $60-70 \%, 4 \%$ is more than $90 \%$ safe, and only $4 \%$ are between $50-60 \%$ safe. Figure 7 shows the graph of the analysis.

Total Numbers based on Percentage of the Safety Level for Safe Campus Area based on Safe City Concept

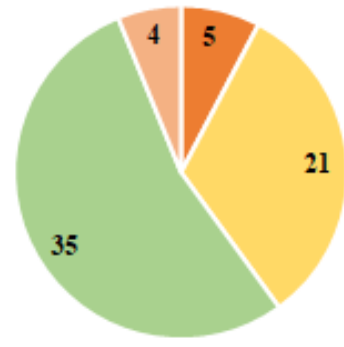

$$
=50-60 \%=60-70 \% \quad=70-80 \% \quad=>90 \%
$$

Figure 7. Percentage of building with Safety Level percentage in UTM Campus.

Table 7 and figure 8 shows the results for Safety Level percentage for all the building in UTM Campus.

\subsection{Discussion}

The results shows that most of the locations for UTM Campus reach safety percentage level above $70 \%$ of the safety level. Out of the total of 65 SC_ID there are 25 SC_ID that are below $70 \%$ for overall scores, and 5 buildings that are in 50-60\% range and 21 buildings that are in $60-70 \%$ range. Most of the buildings are in range of $70-80 \%$ of safety level, which is 35 of the 65 total buildings. And there are only four buildings that are above $90 \%$. The highest percentage of safety level (95\%) is for 4 buildings, which is building F_7, F_11, F_12, and C_9. And the lowest percentage is (53.7\%) buildings FO_4, FO_13, and FO_22.

From the results of all the analysis, it's show that most of the building and area inside UTM Campus are more than 50\% in term of safety level assessment. This show that UTM Campus can be consider as a safe campus based on the Safe City Concept. Besides that, the indicators and sub-indicators that being used in this study can be part of the Safe City Concept or Indicators to assess the safety level of Education Campus.

Some improvement of this model is via having more subindicators, or enhancing the scoring and validation of the indicators process.

\section{CONCLUSION}

This study focuses on assessing the safety level of campus area, with UTM as case study. The analysis done based on the building inside UTM area. The results shows that most of the building in the study area score more than $50 \%$ safety level. This study can facilitate stakeholders related to safety of the campus, including Security Department, or Police Station near the campus, and university's management to improve the safety level, via study the policies related to safety inside the campus. Some enhancement to the indicators also can be made, such as improving the scoring, or including more sub-indicators such as landslide or flooding, to identified the areas that prone to such disaster.

\section{ACKNOWLEDGEMENTS}

Authors would like to express our gratitude to Universiti Teknologi Malaysia for funding this project under the Universiti Teknologi Malaysia, UTM Grant, UTM Fundamental Research Grant (UTMFR), and vote number Q.J130000.2552.21H07. Besides that, authors would also like to express gratitude to UTM's Security Division, and UTM's Property Department for the support and assistant throughout this study.

\section{REFERENCES}

Aris-Anuar, A. N., Jaini, N., Kamarudin, H., \& Nasir, R. A. (2011). Effectiveness evaluation of Safe CityAris-Anuar, A. N., Jaini, N., Kamarudin, H., \& Nasir, R. A. (2011). Effectiveness evaluation of Safe City Programme in relation to the tourism industry. Procedia Engineering, 20, 407-414. Programme in relation to the t. Procedia Engineering, 20, 407-414.

ECU, E. I. U. (2019). Safe City. https://safecities.economist.com/safe-cities-index-2019/

Fesenko, T., Fesenko, G., \& Bibik, N. (2017). The safe city: developing of GIS tools for gender-oriented monitoring (on the example of Kharkiv city, Ukraine). Восточно-Европейский Журнал Передовых Технологий, 3 (2), 25-32.

Hedayati Marzbali, M., Abdullah, A., Ignatius, J., \& Maghsoodi Tilaki, M. J. (2016). Examining the effects of crime prevention through environmental design (CPTED) on Residential Burglary. International Journal of Law, Crime and Justice, 46, 86-102. https://doi.org/10.1016/j.ijlcj.2016.04.001

Keller, E. W., Hughes, S., \& Hertz, G. (2011). A model for assessment and mitigation of threats on the college campus. Journal of Educational Administration.

Lacinák, M., \& Ristvej, J. (2017). Smart city, safety and security. Procedia Engineering, 192, 522-527.

Risdiana, D. M., \& Susanto, T. D. (2019). The Safe City: Conceptual Model Development-A Systematic Literature Review. Procedia Computer Science, 161, 291-299.

Ristvej, J., Lacinák, M., \& Ondrejka, R. (2020). On Smart City and Safe City Concepts. Mobile Networks and Applications, 25(3), 836-845. https://doi.org/10.1007/s11036-020-01524-4

Shamsuddin, S. B., Azim, N., \& Hussin, B. (2013). Safe City Concept and Crime Prevention Through Environmental Design (CPTED) for Urban Sustainability in Malaysian Cities. American Transactions on Engineering \& Applied Sciences, 2(3), 223-245.

Shamsudin, K., Jr, P. V. A., See, T. L., Mohamed, M., Kasim, Z. A., \& UGISP, U. T. M. (n.d.). Safe City Monitoring System: GIS Web Based Application in Crime Monitoring in Malaysia.

Thani, S. K. S. O., Hashim, N. H. M., \& Ismail, W. H. W. (2016). Surveillance by Design: Assessment using principles of Crime Prevention through Environmental Design (CPTED) in 
urban parks. Procedia-Social and Behavioral Sciences, 234, 506-514.

The Economist Intelligence Unit. (2019). Safe Cities Index 2019.

Vitalij, F., Robnik, A., \& Alexey, T. (2012). "Safe City"-an Open and Reliable Solution for a Safe and Smart City. Elektrotehniski Vestnik, 79(5), 262. 